\title{
Perceptions of public transport travel time and their effect on choice-sets among car drivers
}

\author{
Nicolaas Jacob Arnold van Exel \\ Erasmus University Rotterdam ${ }^{\text {a }}$
}

\author{
Piet Rietveld \\ Free University Amsterdam ${ }^{b}$
}

\begin{abstract}
Car drivers' perceptions of the quality of alternative travel modes have been identified as a barrier for including these alternatives in their choice sets. The present study investigated the accuracy of car drivers' perceptions of public transport (PT) travel time and the potential effect of these perceptions on choice sets. A sample of car drivers was intercepted on the main corridors to Amsterdam, the Netherlands, using video recognition of license plates, and was sent a questionnaire asking (among other questions) whether they could have made the specific trip by PT and their estimate of the door-to-door travel time by PT. Objective travel times were obtained from route-planning software. 21,335 questionnaires $(31 \%)$ were returned. About 10 percent did not report PT travel time for their car trip, largely car drivers who did not perceive PT as an alternative. The mean ratio of perceived travel time by PT to reported travel time by car was $1: 2.3$. About half the difference was due to distorted perceptions, and the ratio reported depended strongly on their PT use. Analysis of associations between choice set and characteristics of traveler and trip showed that if perceived PT travel times were more accurate a substantial number of car drivers would include PT in their choice set. Actual changes in behavior might be much smaller.
\end{abstract}

Keywords: Public transport; The Netherlands; Mode choice

\section{Introduction}

Reducing car use is a central topic in transport policy and research. Recent studies have shown that inducing mode change requires both making the car less attractive and increasing travelers' awareness and knowledge of alternative modes of transport (e.g. Handy et al. 2005). One of the main barriers to the use of alternative modes is car drivers' distorted perceptions of the quality of these alternative modes, which have considerable influence on their choice-sets. Kenyon and (Kenyon and Lyons 2003), for instance, found that the majority of travelers rarely considered alternative modes for their journey. Especially on familiar trips, travelers disqualified alternatives in advance, based on subjective perceptions of their viability and desirability. Also, Kingham et al. (2001) observed that one of the main barriers for modal change among car drivers was the perception that alternatives were not viable, in particular with respect to travel time.

Car drivers' perceptions of alternative modes of transport are often not informed by experience or travel information (Kenyon and Lyons 2003). Handy et al. (2005) interviewed car

a(Corresponding author) vanexel@bmg.eur.nl

${ }^{b}$ prietveld@feweb.vu.nl 
drivers about possible reasons for excess car travel and reported that many people said they simply lacked information about alternative modes; only a part of these car drivers was willing to actually try public transport to see whether it would work for them.

Car drivers' perceptions are also often incorrect. Goodwin (1995) found that although $50-80$ percent of people perceived themselves to be generally dependent on car use, only 10-30 percent of trips could unambiguously be identified as both strictly necessary and provided with no alternative. In a corridor study, Kropman and Katteler (1990) found that although 83 percent of a sample of morning peak-period car drivers had the objective possibility to switch to public transport for the trip they were making, only one out of six of these drivers perceived public transport as an alternative-largely because of their perceptions of travel time and travel cost. Brög and Erl (1983) conducted an in-depth analysis of car drivers' travel options and showed that half of their sample of car drivers had the objective opportunity to use public transport for the trip they were making, but that only five percent perceived themselves as having a real choice between car and public transport.

Although distorted perceptions may have a considerable effect on mode choice, there is also evidence that perceptions can be changed and that this may lead to changes in attitudes, consideration of alternatives and mode choice behavior. Kenyon and Lyons (2003) showed that presentation of information to habitual travelers about the cost, duration, comfort, and convenience of alternatives for their trip could challenge existing perceptions and lead to consideration and use of these alternatives. Garvill et al. (2003) found that increasing the awareness of travel mode choice helped decrease car use among people with a strong car habit, because when forced to reconsider people in some cases realized that the car no longer was the best alternative. Rose and Ampt (2001) report similar results. van Knippenberg and van Knippenberg (1988) observed that a temporary behavioral change, due to whatever circumstance, may lead to adjustment of perceptions and, consecutively, to attitudinal change and possibly to adoption of a new travel pattern. van Exel and Rietveld (2001) also found indications that a positive experience with an alternative mode of travel may influence consecutive travel choice.

The present study investigated the accuracy of car drivers' perceptions of public transport travel time in a large sample of Dutch car drivers and the potential effect of changing any distorted perceptions on the travel choice set of these drivers.

\section{Methods}

We conducted secondary analysis on travel survey data collected and processed on behalf of the Dutch Ministry of Transport for the MORA project (Mobility Survey Region Amsterdam; Netherlands Ministry of Transport 2001). The objective of MORA was to gain insight into the accessibility of the City of Amsterdam in order to support regional transport policy development and monitoring. Data collection focused on the composition (in terms of traveler and trip characteristics) of traffic on the six main corridors connecting to the city of Amsterdam. The MORA study covered travel both on roads and on public transport; in this paper, we focus on the data related to private car travel.

A total of 69,616 questionnaires were sent out to car drivers traveling in the direction of Amsterdam on one of the six corridors on any one of three survey days in September 2000. The study sample therefore consisted of non-urban, longer-distance trips ( $\geq 10$ kilometers). Cars were identified through video recognition of license plates. The questionnaire was sent to the 
corresponding address in the national license registry (Mobility Survey Region Amsterdam; Netherlands Ministry of Transport 2001).

The survey questionnaire included general questions concerning trip origin and destination, trip purpose, travel time, and trip frequency of the specific trip made on the day they were observed. It also included a question asking car drivers about their choice set for that trip: "Could you also have made this trip by public transport?", with response categories "no," "yes, but rarely do," and "yes, regularly do." Finally, car users were asked to estimate door-to-door travel time by public transport for the trip they made by car on the day of the survey.

A total of $21,335(30.6 \%)$ questionnaires were returned, of which 17,642 (82.7\%) were useful for analysis. The main source of drop-out was a missing value for public transport travel time perception: 2,110 observations ( $57 \%$ drop-out). This largely concerned car drivers who answered "no" to the question "Could you also have made this trip by public transport?" $(90.1 \%$ of missing travel time values). Apparently, segments of the population that do not consider public transport as an alternative also know little about it. Although these respondents were excluded from further analysis here, this is a first important observation.

To assess the accuracy of public transport travel time perceptions, we estimated the 'objective' travel time by public transport using trip origin and destination (OD) information and Web-based route planning software (http://www.ns.nl, http://www.9292ov.nl). The public transport trip was assumed to consist of a rail origin-to-destination link, as well as access and egress travel. In the MORA dataset, trip origin and destination were available as city or region name; for trips to the City of Amsterdam, destination data was available at the level of nine city districts. Observations with only a region name as origin or destination were excluded from further analysis because it was impossible to approximate public transport travel time with sufficient accuracy. For the remaining observations, rail travel time was calculated as intercity central station to central station for through traffic, and intercity central to the most appropriate of five rail stations in Amsterdam for trips to one of the nine city districts. Access and egress times were estimated at the level of all different points of origin and destination. Mean access and egress times varied between 10 and 30 minutes, depending on zone size and using a "donut approach." In this way, we were able to determine a fair estimate of the "objective" travel time by public transport for 6318 car travelers (32.9\% of the total sample). This sub-sample consists of shorter trips as compared to the total sample (average car travel time 48 vs. 67 minutes; $p<0.001$, two-sample $t$-test), because most long-distance trips had a region name as origin and/or destination and, as explained above, were therefore excluded from this analysis.

To investigate the effect of car drivers' public transport travel time perceptions on the inclusion of public transport in their choice-set for the trip they made on the day of the survey, we looked at the relation between answers to the question "Could you also have made this trip by public transport?" (response categories "no", "yes, but rarely do" and "yes, regularly do") and characteristics of the traveler and the trip.

Define $Y$ as the perceived possibility of using public transport for the trip that was actually made by car. Here, $Y$ is a trichotomous variable, where $Y=0,1$, and 2 stand for "no," "yes,

\footnotetext{
${ }^{1}$ We assumed that each central station was in the center of a zone, that people in the car sample were unlikely to live directly near the central station, and that the population density of a zone decreased proportionally with travel distance from the central station. Therefore, in estimating mean access and egress times for any zone, we disregarded the parts of the zone that were either within approximately five minutes travel distance of central station (the hole in the "donut") or more than 30 minutes travel distance of central station (the outer edge of the "donut").
} 
but rarely do," and "yes, regularly do," respectively. Let $i$ denote an individual traveler. The probability that $Y=j$ depends on features of the trip made by individual $i$, in terms of trip destination, purpose, reported travel time by car, who pays for the trip, and other relevant features listed in Table 3; these variables are denoted as $x_{i 1}, \ldots, x_{i \mathrm{~N}}$. Then, in the multinomial model, the probability that individual $i$ will choose alternative $j$ is formulated as:

$$
\begin{gathered}
P(Y=j)=\frac{\exp \left(\sum_{n} x_{i n} \beta_{j}\right)}{1+\exp \left(\sum_{n} x_{i n} \beta_{1}\right)+\exp \left(\sum_{n} x_{i n} \beta_{2}\right)} \\
\text { for } j=1,2 ; P(Y=0)=1-P(Y=1)-P(Y=2) .
\end{gathered}
$$

Unlike ordered models, a multinomial models like the one described above allow the coefficients of the explanatory variables to vary across the alternatives; for example, trip purpose can have a different effect on the different response categories. Multinomial logistic regression was conducted with the response category "no" as reference value. Because the coefficients of multinomial logit models are generally difficult to interpret, marginal effects were estimated and are presented for ease of interpretation. Marginal effects have the appealing characteristic that the sum over the response categories is always zero.

Next, the coefficients of the multinomial logit model (see Appendix) were used to estimate car drivers' likely answer to the question "Could you also have made this trip by public transport?" under the condition that they were better informed about the objective public transport travel time. For this, we substituted perceived public transport travel times reported by individual car drivers with OD-based public transport travel time obtained from web-based route planning software, all else equal, and compared predicted response frequencies.

All analyses were conducted in Stata/SE 10.

\section{Results}

The mean travel time by car of the trip made on the day of the survey was 60 minutes. The mean perceived travel time by public transport for that same trip was almost double: 117 minutes. Table 1 shows that the mean ratio of perceived public transport and reported car travel time was $1: 2.3$ and that this ratio was inversely related to car travel time.

At first glance, it appears that car drivers add about an hour to their car travel time when asked to estimate public transport travel time for the same trip, independent of trip distance. To investigate this more closely, we conducted regression analysis of perceived public transport travel time, using travel time by car, travel time by public transport (based on OD data), trip frequency, experience with public transport, trip destination and time of day as explanatory variables. Table 2 shows that the perception of public transport travel time is positively associated with both reported car travel time and the objective public transport travel time. The perceived duration of the public transport trip decreases with familiarity with the trip (i.e., trip frequency) and the public transport system (i.e., experience with public transport on this trip). It is also lower for trips ending in Amsterdam than for through traffic, presumably because of 
Table 1: Reported travel time by car versus perceived travel time by public transport for the same trip $(\mathrm{N}=17642)$

\begin{tabular}{|c|c|c|c|c|c|c|c|c|}
\hline & \multirow[t]{2}{*}{$\mathrm{N}$} & \multirow[t]{2}{*}{$\%$} & \multicolumn{2}{|c|}{$\begin{array}{l}\text { Reported } \\
\text { travel time by } \\
\text { car (min.) }\end{array}$} & \multicolumn{3}{|c|}{$\begin{array}{l}\text { Perceived travel time } \\
\text { by public transport } \\
\text { (min.) }\end{array}$} & \multirow[b]{2}{*}{$\begin{array}{l}\text { Ratio } \\
\text { to car }\end{array}$} \\
\hline & & & mean & SD & mean & SD & $\begin{array}{l}\text { Difference } \\
\text { w/ car }\end{array}$ & \\
\hline \multicolumn{9}{|c|}{ Reported travel time by car: } \\
\hline $0-30 \mathrm{~min}$ & 3546 & $-20.10 \%$ & 25.3 & 5.4 & 82.6 & 34.1 & 57.3 & 3.5 \\
\hline $31-60 \mathrm{~min}$. & 8485 & $-48.10 \%$ & 48.1 & 8.4 & 104.6 & 37.1 & 56.4 & 2.2 \\
\hline $61-90 \mathrm{~min}$. & 3371 & $-19.10 \%$ & 77.7 & 8.6 & 137.7 & 44.8 & 60.0 & 1.8 \\
\hline $91-120 \mathrm{~min}$. & 1302 & $-7.40 \%$ & 110.0 & 8.2 & 172.8 & 58.9 & 62.8 & 1.6 \\
\hline$>120 \mathrm{~min}$ & 938 & $-5.30 \%$ & 162.2 & 43.6 & 206.2 & 70.6 & 44.0 & 1.3 \\
\hline \multicolumn{9}{|c|}{ Could you also have made this trip by public transport? } \\
\hline no & 9747 & $-55.20 \%$ & 60.7 & 36.0 & 130.3 & 55.0 & 69.6 & 2.5 \\
\hline yes, but rarely do & 6943 & $-39.40 \%$ & 58.3 & 35.1 & 101.9 & 46.5 & 43.6 & 2.0 \\
\hline \multirow[t]{2}{*}{ yes, regularly do } & 952 & $-5.40 \%$ & 62.1 & 35.6 & 89.2 & 44.1 & 27.1 & 1.6 \\
\hline & 17642 & & 59.8 & 35.6 & 116.9 & 53.4 & 57.1 & 2.3 \\
\hline
\end{tabular}

the density of public transport services to and within the city as compared to smaller towns or rural areas, and even more so for trips to the city center. Finally, we found a traffic congestion effect: car drivers who made their trips during peak periods estimated lower public transport travel times.

The ratio of perceived public transport travel time and reported car travel time was also inversely related to respondents' experience with public transport on the same trip (see Table 1). The "chicken and egg" question, then, is whether people who use public transport less often have a less favorable view of public transport as an alternative for their trip, or that people who have a less favorable public transport connection on their trip use public transport less often. Table 3 shows that both effects appear to play a role here. The first columns of Table 3 contain the same information as those of Table 1, but for the smaller sub-sample of 6,318 car drivers for which OD-based public transport travel time could be estimated. The ratio of perceived public transport to car travel time, and the association of this ratio with public transport experience, echoed the findings from the full sample (see Table 1). Mean OD-based public transport travel time was 67 minutes, about one-third lower than perceived travel time and comparable for car drivers of all three levels of public transport experience. The last two columns of Table 3 show that the ratio between perceived and objective public transport travel time $(1: 1.5)$ and the ratio between objective public transport and reported car travel time $(1: 1.6)$ are of comparable magnitude, and are associated with public transport experience; the latter relation was statistically significantly $(p<0.001$, ANOVA). This coincides with earlier findings by Rooijers (1998), who observed that regular public transport users perceive reliability of public transport to be higher than do occasional users and non-users.

The relation between public transport experience and the ratio between objective public transport and reported car travel time (last column of Table 3) indicates that people with more 
Table 2: Determinants of perceived public transport travel time $(\mathrm{N}=6318)$.

\begin{tabular}{lrrrrrr}
\hline & Coef. & S.E. & $t$ & \multicolumn{2}{c}{$95 \%$ C.I. } \\
\hline Reported travel time by car & 0.3 & 0 & 17.9 & 0.3 & 0.4 \\
Objective travel time by PT & 0.5 & 0 & 21.5 & 0.5 & 0.5 \\
Trip frequency & & & & & & \\
1-2 times/week & 5.8 & 1.2 & 4.9 & 3.5 & 8.2 \\
Less than once/week & 10.7 & 1.0 & 11.2 & 8.8 & 12.6 \\
Trip destination & & & & & \\
Amsterdam & -1.9 & 1.7 & -1.1 & -5.1 & 1.4 \\
Amsterdam City Center & -2.2 & 1.0 & -2.3 & -4.1 & -0.4 \\
Time of day: Peak period & -3.1 & 0.8 & -3.7 & -4.8 & -1.5 \\
Could you also have made this trip by public transport ?c & & \\
No & 37.5 & 1.7 & 22.1 & 34.2 & 40.8 \\
Yes, but rarely do & 17.2 & 1.7 & 10.0 & 13.8 & 20.5 \\
Constant & 22.0 & 2.8 & 7.8 & 16.4 & 27.5 \\
\hline
\end{tabular}

Note: Dependent variable: perceived public transport travel time. Reference values independent variables: ${ }^{a} 3$ times a week or more. ${ }^{b}$ through-traffic; "Amsterdam City Center" is a subset of "Amsterdam." c "yes, regularly do." $R^{2}=0.28$.

Table 3: Travel time by car versus perceived and OD-based travel time by public transport for the same $\operatorname{trip}(N=6318)$.

\begin{tabular}{|c|c|c|c|c|c|c|c|c|}
\hline & \multirow[t]{2}{*}{$N$} & \multirow[t]{2}{*}{$\%$} & \multirow{2}{*}{$\begin{array}{l}\text { Reported } \\
\text { travel time by } \\
\frac{\operatorname{car}(\min .)}{\text { mean }}\end{array}$} & \multicolumn{2}{|c|}{$\begin{array}{l}\text { Perceived travel } \\
\text { time by public } \\
\text { transport (min.) }\end{array}$} & \multicolumn{3}{|c|}{$\begin{array}{l}\text { OD-based travel } \\
\text { time by public } \\
\text { transport (min.) }\end{array}$} \\
\hline & & & & mean & $\begin{array}{l}\text { ratio to } \\
\text { car }\end{array}$ & mean & $\begin{array}{l}\text { ratio to } \\
\text { perceived }\end{array}$ & $\begin{array}{l}\text { ratio to } \\
\text { car }\end{array}$ \\
\hline \multicolumn{9}{|c|}{ Could you also have made this trip by public transport? } \\
\hline no & 3246 & $(51.4 \%)$ & 46.9 & 109.4 & 2.7 & 67.8 & 1.7 & 1.7 \\
\hline yes, but rarely do & 2680 & $(42.4 \%)$ & 47.8 & 87.5 & 2.1 & 65.9 & 1.4 & 1.6 \\
\hline yes, regularly do & 392 & $(6.2 \%)$ & 52.2 & 75.4 & 1.7 & 68.4 & 1.1 & 1.5 \\
\hline Total & 6318 & & 47.6 & 98.0 & 2.4 & 67.0 & 1.5 & 1.6 \\
\hline
\end{tabular}


favorable connections apparently use public transport more often. The effect of public transport experience on the ratio between perceived and objective public transport travel time is much larger, however, indicating that car drivers' choice sets may be more strongly affected by the perception that public transport travel times are less favorable than by the reality of less favorable travel times relative to traveling by car. In addition, the ratio of $1: 1.1$ between perceived and objective public transport travel time for car drivers who regularly use public transport indicates this group has a fairly accurate perception of public transport travel time, considering that the objective times used here were based on public transport schedules (i.e., planned travel times) and that the punctuality of rail services at the time was moderate: About 18 percent of trains had a delay of three minutes or more, and 10 percent of train-to-train connections were missed as a result of these delays (van Exel 2003).

If car drivers' perceptions of public transport travel time deviate substantially from objective travel times, what would be the potential gain from improving the accuracy of these perceptions? To investigate this, we first analyzed associations of car drivers' answers to the question "Could you also have made this trip by public transport?" "no" = 51.4\%; "yes, but rarely do" $=42.4 \%$; "yes, regularly do" $=6.2 \%$; see Table 3 ) with characteristics of the traveler and the trip. Table 4 (see also Appendix) shows that the possibility of using public transport on the trip made on the day of the survey was higher for trips to the city center, commuting trips, trips made for educational purposes, and for people paying for the trip themselves. The possibility was lower for business trips and trips made very frequently; it decreased with trip distance and reported travel time by public transport relative to car, for people driving a leased or company car, for those driving alone, for those who had a parking place available at their destination on private grounds, for those who shifted their departure time in order to avoid congestion, and for trips paid by the employer. Apparently, car drivers traveling alone for business purposes in a company-owned or leased car, with a poor image of public transport in terms of travel time relative to car, and their trip costs covered by the employer are most resistant to considering public transport as a travel alternative. Of all car drivers, their travel behavior seems most inert.

Some of the coefficients in the model were not statistically significant. Time of day and paying for parking at trip origin or destination showed no effect on the possibility to use public transport. That time of day had no effect is remarkable, but this effect may have been picked up by other variables in the model. For instance, the effect of congestion during peak hours may be fully reflected in the shifted departure time variable, whereas some of the other time-of-day dynamics may be incorporated into the trip purpose variables. The lack of effect in the paid public parking variable must be considered against the comparator, i.e. free public parking and the private parking variables. Taken together, we speculate that there is no difference in resistance between the cost of paid parking and the anticipated time needed to find a parking place when public parking is free of charge (but often otherwise restricted and limited in capacity).

In addition there are some variables that affect only one or two of the three response categories. Most of these (lack of) association(s), however, seem plausible and support the choice of a multinomial rather than an ordinal logit model.

Next, we compared the response predicted by this model with the likely response when we substituted perceived public transport travel time with objective OD-based travel time (in the "travel time ratio PT:car" variable). This analysis showed that the response was the same for 63.6 percent of car drivers (see shaded cells in Table 5) but that a substantial number of car drivers would shift from the "no" response category to the "yes, but rarely do" response category. This 
Table 4: Possibility of using public transport among car travelers; marginal effects from multinomial logit model $(N=6318)$.

\begin{tabular}{|c|c|c|c|c|c|c|}
\hline & \multicolumn{6}{|c|}{ Could you also have made this trip by public transport? } \\
\hline & \multicolumn{2}{|c|}{ Yes, regularly do a } & \multicolumn{2}{|c|}{ Yes, but rarely do ${ }^{b}$} & \multicolumn{2}{|c|}{$\mathrm{No}^{\mathrm{c}}$} \\
\hline & $\mathrm{dy} / \mathrm{dx}$ & S.E. & $\mathrm{dy} / \mathrm{dx}$ & S.E. & $\mathrm{dy} / \mathrm{dx}$ & S.E. \\
\hline Destination: A'dam city center & 0.002 & 0.008 & $0.099^{* *}$ & 0.030 & $-0.101^{* *}$ & 0.030 \\
\hline Destination: A'dam periphery & 0.005 & 0.007 & 0.045 & 0.028 & $-0.049^{*}$ & 0.028 \\
\hline Trip purpose: commute & $0.026^{* * *}$ & 0.006 & -0.006 & 0.022 & -0.020 & 0.023 \\
\hline Trip purpose: business & 0.006 & 0.008 & $-0.106^{* * *}$ & 0.024 & $0.101^{* * *}$ & 0.024 \\
\hline Trip purpose: education & $0.079^{*}$ & 0.031 & -0.010 & 0.050 & -0.068 & 0.053 \\
\hline Trip frequency: high ${ }^{\mathrm{d}}$ & $-0.053^{* * *}$ & 0.009 & 0.022 & 0.020 & 0.032 & 0.020 \\
\hline Time of day: peak hours & -0.004 & 0.004 & 0.000 & 0.014 & 0.004 & 0.015 \\
\hline Reported travel time by car & $-0.001^{* * *}$ & 0.000 & $-0.004^{* * *}$ & 0.000 & $0.004^{* * *}$ & 0.000 \\
\hline Travel time ratio PT:car & $-0.049^{* * *}$ & 0.003 & $-0.176^{* * *}$ & 0.010 & $0.225^{* * *}$ & 0.010 \\
\hline Car ownership: company & $-0.020^{* *}$ & 0.006 & $-0.110^{* * *}$ & 0.031 & $0.130^{* * *}$ & 0.031 \\
\hline Car ownership: leased & -0.010 & 0.007 & $-0.061^{*}$ & 0.030 & $0.071^{*}$ & 0.031 \\
\hline Car occupancy: driver only & 0.005 & 0.005 & $-0.049^{* *}$ & 0.019 & $0.044^{*}$ & 0.019 \\
\hline Parking origin: private & $-0.007^{*}$ & 0.004 & $-0.038^{* *}$ & 0.014 & $0.045^{* *}$ & 0.014 \\
\hline Parking origin: public (paying) & -0.002 & 0.007 & 0.014 & 0.028 & -0.012 & 0.029 \\
\hline Parking dest.: private & -0.003 & 0.004 & $-0.032 *$ & 0.016 & $0.035^{*}$ & 0.017 \\
\hline Parking dest.: public (paying) & -0.001 & 0.005 & 0.006 & 0.018 & -0.005 & 0.018 \\
\hline Shifted departure time: yes & $-0.008^{*}$ & 0.004 & $-0.029^{*}$ & 0.014 & $0.036^{*}$ & 0.015 \\
\hline Paying for trip: me & -0.006 & 0.007 & $0.044^{*}$ & 0.024 & -0.037 & 0.025 \\
\hline Paying for trip: employer & $-0.016^{* *}$ & 0.005 & -0.018 & 0.017 & $0.034 *$ & 0.017 \\
\hline
\end{tabular}

Note: ${ }^{* * *} p<0.001 ;{ }^{* *} p<0.01 ;{ }^{*} p<0.10$. Reference case: a through-traffic car trip for social or recreational purpose, made less than once a week, off-peak, in a privately owned car, using a public parking place free of charge at origin and destination, without shifting departure time to avoid congestion. See appendix A for coefficients from multinomial logit model. ${ }^{\text {a }} N=392$ (6.2\%). ${ }^{\mathrm{b}} N=2680(42.4 \%) .{ }^{\mathrm{c}} N=3246(51.4 \%) .{ }^{\mathrm{d}}$ Once a week or more.

Table 5: Could you also have made this trip by public transport? $(N=6318)$.

\begin{tabular}{|c|c|c|c|c|c|c|}
\hline & & \multicolumn{3}{|c|}{$\begin{array}{l}\text { Predicted values based on OD- } \\
\text { based public transport travel time }\end{array}$} & \multicolumn{2}{|c|}{ Total } \\
\hline & & $\begin{array}{l}\text { Yes, } \\
\text { regularly }\end{array}$ & $\begin{array}{l}\text { Yes, } \\
\text { rarely }\end{array}$ & No & & \\
\hline \multirow{3}{*}{$\begin{array}{l}\text { Predicted values based } \\
\text { on perceived public } \\
\text { transport travel time }\end{array}$} & Yes, regularly & 10 & 12 & 4 & 26 & $(0.4 \%)$ \\
\hline & Yes, rarely ${ }^{\mathrm{b}}$ & 8 & 2608 & 270 & 2886 & $(45.7 \%)$ \\
\hline & $\mathrm{No}^{\mathrm{c}}$ & 11 & 1996 & 1399 & 3406 & $(53.9 \%)$ \\
\hline Total & & $\begin{array}{c}29 \\
(0.5 \%)\end{array}$ & $\begin{array}{c}4,616 \\
(73.1 \%)\end{array}$ & $\begin{array}{c}1,673 \\
(26.5 \%)\end{array}$ & & \\
\hline
\end{tabular}

Note: ${ }^{a} \mathrm{~N}=392$ (6.2\%). ${ }^{\mathrm{b}} \mathrm{N}=2,680$ (42.4\%). ${ }^{\mathrm{c}} \mathrm{N}=3,246(51.4 \%)$. 
indicates that improving the accuracy of car drivers' perceptions of public transport travel time will lead to a larger proportion of car drivers including public transport in their travel choice sets, and perhaps using public transport instead of their cars from time to time.

\section{Discussion}

This study investigated the accuracy of car drivers' perceptions of public transport travel time and the potential effect of these perceptions on car drivers' choice sets. The research was carried out on a large sample of car drivers intercepted on the main corridors leading to Amsterdam, using a combination of reported data collected through a questionnaire and objective data obtained from web-based route planning software.

Our results confirm the findings of earlier studies that used different methodologies: car drivers' perceptions of public transport travel time sometimes deviate substantially from real travel times, and these deviations can be partly explained by familiarity with the trip and characteristics of the trip and the public transport system. ${ }^{2}$ Our results also suggest that providing better information to car drivers about objective travel times for the public transport alternative for their trips-which is the aim of many travel demand management (TDM) initiatives adopted internationally - may lead to a much higher proportion of car drivers including public transport in their travel choice sets.

The size of this effect is, however, subject to some uncertainty. First, there are some limitations with respect to the way 'objective' travel time was calculated. We used mean access and egress times for people traveling to or from a specific zone, while considerable variations may exist, especially in the larger zones. This may contribute to selection bias, as people on the upper ends of this variation may be more likely to have chosen car as their preferred option and may thus be overrepresented in the sample. Second, our implicit hypothesis has been that inaccurate perceptions result from lack of knowledge, and that behavioral change would be stimulated by information policies. An alternative explanation could be that the distorted perceptions of public transport travel times among car users are the result of conscious or unconscious processes related to their mode choice. For instance, some car users may deliberately overestimate public transport travel time as a form of justification for their car use by emphasizing the impossibility of using public transport. March (1997), for instance, argued that decision making in a social context ultimately is linked to making sense. People feel the need to justify their behaviors to themselves and others and therefore, either before (Dawes 1999) or after (Festinger 1957) making a choice, and this need leads them to construct compelling, socially acceptable stories that make their behavior consistent with their individual preferences as well as with the expectations from (relevant, important) others. ${ }^{3}$ This has two possible implications for the results of the present study. First, deliberate overestimation may lead to inflation of public transport travel time perceptions, indicating that our findings represent an upper boundary of the

${ }^{2}$ It has been shown that subjective expectations may also deviate considerably from their objective counter facts for (other) central issues in peoples' lives, such as life expectancy (Brouwer and van Exel 2005; Hamermesh 1985; Mirowky 1999).

${ }^{3}$ Providing better information may, in turn, affect such processes by confining the size of overestimation that is socially acceptable. For instance, whereas a few years ago in the Netherlands a train delay was a perfectly acceptable story for arriving late at an appointment (van Exel 2003), the combination of better performance in recent years and an information campaign from the national railways company have made it far less credible and accepted today. 
effect. Second, for some car users the sensitivity of the choice set to information about objective public transport time may be more limited than the results of our analysis suggest. In either case, our estimation of the effect of inaccurate public transport travel time perceptions on car users' choice sets would be an overestimation. In summary, both the uncertainty in estimating "objective" public transport travel time and the possibility that some car users have consciously distorted "subjective" public transport travel times behoove us to be cautious in drawing conclusions from our findings, and warrant additional research to find supporting evidence.

Both reasons - the gap between adding an alternative to one's choice-set and actually choosing this alternative, and psychological processes related to justification processes-imply that the change in proportion of car drivers that will actually travel by public transport regularly may be much smaller. This confirms findings of, among others, Hensher and Puckett (2007), Gärling and Schuitema (2007), Chorus et al. (2006), and Loukopoulos et al. (2004). Nonetheless, often only small changes in traffic are needed to decrease congestion considerably.

\section{References}

Brouwer, W. and N. van Exel. 2005. Expectations regarding length and health related quality of life: Some empirical findings. Social Science \& Medecine, 61(5):1083-1094.

Brög, W. and E. Erl. 1983. Application of a model of individual behaviour (situational approach) to explain household activity patterns in an urban area and to forecast behavioural changes. In S. Carpenter and P. Jones, eds., Recent advances in travel demand analyis. Aldershot.

Chorus, C., E. Molin, B. V. Wee, T. Arentze, and H. Timmermans. 2006. Responses to transit information among car-drivers: Regret-based models and simulations. Transportation Planning and Technology, 29(4):249-271.

Dawes, R. 1999. A message from psychologists to economists: Mere predictability doesn't matter like it should (without a good story to append to it). Journal of Economic Behavior \& Organization, 39:29-40.

Festinger, L. 1957. A theory of cognitive dissonance. Stanford University Press.

Garvill, J., A. Marell, and A. Nordlund. 2003. Effects of increased awareness on choice of travel mode. Transportation, 30:63-79.

Goodwin, P. 1995. Car dependence. Transportation, 2(3):151-152.

Gärling, T. and G. Schuitema. 2007. Travel demand management targeting reduced private car use: Effectiveness, public acceptability and political feasibility. Journal of Social Issues, 63(1):139-153.

Hamermesh, D. 1985. Expectations, life expectancy, and economic behavior. The Quarterly Journal of Economics, 100(2):389-408.

Handy, S., L. Weston, and P. Mokhtarian. 2005. Driving by choice or necessity? Transportation Research Part A, 39(2/3):183-204.

Hensher, D. and S. Puckett. 2007. Congestion and variable user charging as an effective travel demand management instrument. Transportation Research Part A, 41(7):615-626.

Kenyon, S. and G. Lyons. 2003. The value of integrated multimodal information and its potential contribution to modal change. Transportation Research Part F, 6:1-21.

Kingham, S., J. Dickinson, and S. Copsey. 2001. Travelling to work: Will people move out of their cars? Transport Policy B, 8(151-160). 
Kropman, J. and H. Katteler. 1990. Files in de Randstad, oplossingen op het spoor? Onderzoek naar substitutiemogelijkheden voor het autogebruik op de corridor Dordrecht-Rotterdam (In Dutch); [Traffic jams in the Randstad, solutions on rails? An investigation of possibilities for substitution of car use on the Dordrecht-Rotterdam corridor]. Nijmegen, The Netherlands: ITS Institute for Applied Social Sciences.

Loukopoulos, P., C. Jakobssona, T. Gärlinga, C. Schneider, and S. Fujii. 2004. Car-user responses to travel demand management structures: Goal setting and choice of adaptation alternatives. Transportation Research D, 9(4):263-280.

March, J. 1997. Understanding how decisions happen in organizations. In Z. Shapira, ed., Organizational decision making. Cambridge University Press.

Mirowky, J. 1999. Subjective life expectancy in the u.s.: Correspondence to actual estimates by age, sex and race. Social Science \& Medecine, 49(7):967-979.

Netherlands Ministry of Transport. 2001. Mobiliteitsonderzoek Regio Amsterdam. Haarlem, The Netherlands: Ministry of Transport, DG Rijkswaterstaat, Directorate Noord-Holland. Rooijers, A. 1998. Betrouwbaarheid van vervoerwijzen: Percepties en gedragsaanpassingen van de reizigers (In Dutch) [The reliability of transport modes: Perceptions and travellers' behavioural response]. The Hague: Project Office for Integrated Traffic \& Transport Studies (PbIVVS).

Rose, G. and E. Ampt. 2001. Travel blending: an Australian travel awareness initiative. Transportation Research D, 6(2):95-110.

van Exel, N. 2003. Van het begane spoor: subjectieve betrouwbaarheid, tevredenheid en heroverweging van forenzen per openbaar vervoer $(\mathrm{n}=1)$ (in Dutch) [off the beaten track: subjective reliability, satisfaction and reconsideration of commuting by public transport $(\mathrm{n}=1)$ ]. In Proceedings of Colloquium Vervoersplanologisch Speurwerk. Working paper.

van Exel, N. and P. Rietveld. 2001. Public transport strikes and traveller behaviour. Transport Policy, 8(4):237-246.

van Knippenberg, D. and C. van Knippenberg. 1988. Beïnvloeding van vervoermiddelkeuze in het woon-werkverkeer door middle van een tijdelijke gedragsverandering (in Dutch) [Influencing mode choice in commuting travel by means of an induced temporary behavioural change]. Report VK 88-11, Traffic Research Centre, University of Groningen, Groningen. 


\section{Appendix}

Table 6: Results of multinomial logit model $(N=6318)$.

\begin{tabular}{|c|c|c|c|c|c|c|c|c|c|c|}
\hline & \multicolumn{10}{|c|}{ Could you also have made this trip by public transport? } \\
\hline & \multicolumn{5}{|c|}{ Yes, regularly do } & \multicolumn{5}{|c|}{ Yes, rarely do } \\
\hline & $\mathrm{B}$ & & S.E. & $95 \%$ & $\%$ CI & $\mathrm{B}$ & & S.E. & $95 \%$ & $6 \mathrm{CI}$ \\
\hline $\begin{array}{l}\text { Destination: A'dam city } \\
\text { centre }\end{array}$ & 0.260 & & 0.250 & & -0.230 & 0.417 & ** & 0.125 & & 0.171 \\
\hline $\begin{array}{l}\text { Destination: A'dam } \\
\text { periphery }\end{array}$ & 0.231 & & 0.238 & -0.236 & 0.697 & 0.197 & * & 0.118 & -0.034 & 0.429 \\
\hline Trip purpose: commute & 0.846 & $* * *$ & 0.202 & 0.450 & 1.241 & 0.024 & & $0.094-$ & -0.160 & 0.207 \\
\hline Trip purpose: business & -0.010 & & 0.219 & -0.438 & 0.419 & -0.450 & $* * *$ & 0.107 & -0.660 & -0.241 \\
\hline Trip purpose: education & 1.367 & $* * *$ & 0.340 & 0.700 & 2.034 & 0.111 & & 0.222 & -0.324 & 0.545 \\
\hline Trip frequency: high ${ }^{a}$ & -1.275 & $* * *$ & 0.171 & -1.611 & -0.939 & -0.007 & & 0.084 & -0.172 & 0.158 \\
\hline $\begin{array}{l}\text { Time of day: peak } \\
\text { hours }\end{array}$ & -0.126 & & 0.122 & -0.366 & 0.114 & -0.008 & & 0.060 & -0.125 & 0.110 \\
\hline $\begin{array}{l}\text { Reported travel time by } \\
\text { car }\end{array}$ & -0.024 & ${ }^{* * *}$ & 0.003 & -0.030 & -0.018 & -0.017 & $* * *$ & 0.002 & -0.020 & -0.013 \\
\hline Travel time ratio PT:car & -1.883 & $* * *$ & 0.110 & -2.098 & -1.668 & -0.828 & $* * *$ & 0.041 & -0.908 & -0.748 \\
\hline $\begin{array}{l}\text { Car ownership: } \\
\text { company }\end{array}$ & -1.063 & $* *$ & 0.389 & -1.826 & -0.300 & -0.510 & $* * *$ & 0.141 & -0.786 & -0.235 \\
\hline Car ownership: leased & -0.490 & $*$ & 0.293 & -1.065 & 0.084 & -0.278 & $*$ & 0.131 & -0.535 & -0.020 \\
\hline $\begin{array}{l}\text { Car occupancy: driver } \\
\text { only }\end{array}$ & 0.077 & & 0.162 & -0.240 & 0.395 & -0.195 & * & 0.077 & -0.347 & -0.044 \\
\hline Parking origin: private & -0.288 & $*$ & 0.120 & -0.523 & -0.053 & -0.173 & ** & 0.058 & -0.288 & -0.059 \\
\hline $\begin{array}{l}\text { Parking origin: public } \\
\text { (paying) }\end{array}$ & -0.045 & & 0.227 & -0.490 & 0.400 & 0.056 & & 0.118 & -0.176 & 0.287 \\
\hline Parking dest.: private & -0.157 & & 0.141 & -0.434 & 0.119 & -0.141 & $*$ & 0.069 & -0.275 & -0.007 \\
\hline $\begin{array}{l}\text { Parking dest.: public } \\
\text { (paying) }\end{array}$ & -0.027 & & 0.151 & -0.322 & 0.268 & 0.023 & & 0.074 & -0.123 & 0.169 \\
\hline $\begin{array}{l}\text { Shifted departure time: } \\
\text { yes }\end{array}$ & -0.307 & $*$ & 0.124 & -0.549 & -0.065 & -0.135 & * & 0.061 & -0.254 & -0.016 \\
\hline Paying for trip: me & -0.116 & & 0.209 & -0.527 & 0.294 & 0.174 & * & 0.102 & -0.026 & 0.375 \\
\hline $\begin{array}{l}\text { Paying for trip: } \\
\text { employer }\end{array}$ & -0.540 & $* * *$ & 0.149 & -0.831 & -0.248 & -0.104 & & 0.072 & -0.245 & 0.037 \\
\hline Constant & 2.453 & $* * *$ & 0.494 & 1.484 & 3.421 & 2.612 & $* * *$ & 0.241 & 2.139 & 3.085 \\
\hline
\end{tabular}

